\title{
ANALISIS PENGARUH PERTUMBUHAN EKONOMI, UPAH MINIMUM DAN INDEKS PEMBANGUNAN MANUSIA TERHADAP TINGKAT PENGANGGURAN DI PROVINSI JAWA TIMUR TAHUN 2008-2014
}

\author{
Muhammad Nurcholis \\ PT. Blue Birds \\ E-mail: Muhammad20102014@gmail.com
}

\begin{abstract}
In this study, the expected goal is to determine the distribution, classification and influence economic growth, minimum wage, and the Human Development Index of the level of unemployment in East Java Province 2008-2012. This research uses descriptive quantitative research methods. Data analysis in accordance with the formulation of the problem and the purpose of the study is using panel data regression analysis model and using the classification of the intensity and GIS. Based on panel data regression results show that perumbuhan economy, the minimum wage and the human development index have a significant effect on the unemployment rate. Variable economic growth and the negative effect of minimum wages, while the human development index positive effect. As for testing the $F$ calculation, economic growth, the minimum wage and the human development index have a significant effect on the unemployment rate.
\end{abstract}

Keywords: unemployment rate, economic growth, minimum wage, human development index

\section{ABSTRAK}

Dalam penelitian ini tujuan yang di harapkan adalah untuk mengetahui distribusi, klasifikasi dan pengaruh pertumbuhan ekonomi, upah minimum, dan Indeks Pembangunan Manusia terhadap tingkat pengangguran di Provinsi Jawa Timur tahun 2008-2012. Penelitian ini menggunakan metode penelitian diskriptif kuantitatif. Teknik analisa data yang sesuai dengan perumusan masalah dan tujuan penelitian adalah menggunakan model analisis regresi data panel serta menggunakan klasifikasi intensitas dan GIS. Berdasarkan hasil regresi data panel menunjukan bahwa perumbuhan ekonomi, upah minimum dan indeks pembangunan manusia berpengaruh signifikan terhadap tingkat pengangguran. Variabel pertumbuhan ekonomi dan upah minimum berpengaruh negatif, sedangkan indeks pembangunan manusia berpengaruh positif. Sedangkan untuk pengujian $F$ hitung, pertumbuhan ekonomi, upah minimum dan indeks pembangunan manusia berpengaruh signifikan terhadap tingkat pengangguran.

Kata Kunci :Tingkat pengangguran, Pertumbuhan ekonomi, Upah minimum, Indeks pembangunan manusia. 


\section{PENDAHULUAN}

Indonesia merupakan salah satu negara berkembang yang masih mengalami proses pembangunan ekonomi yang memiliki tujuan untuk mencapai suatu kesejahteraan masyarakat, dalam mencapai suatu kesejahteraan salah satunya dibutuhkan kesempatan kerja yang mendukung dan adanya pemerataan pendapatan di masyarakat, di Indonesia antara kesempatan kerja yang ada dengan angkatan kerja terjadi kesenjangan yaitu peningkatan jumlah kesempatan kerja tidak sebanding dengan peningkatan angkatan kerja yang meningkat lebih cepat, hal ini akan berdampak pada terciptanya pengangguran Pengangguran yang terjadi akan memiliki dampak terhadap kehidupan sosial yaitu tingkat kriminal dan kekerasan, hal ini akan berpengaruh pada stabilitas dan pembangunan ekonomi akan terhambat serta kesehjateraan akan berkurang. Penganguran merupakan permasalahan yang terjadi di berbagi daerah di Indonesia salah satunya adalah Provinsi Jawa Timur yang memiliki jumlah penduduk kurang lebih 38.052.950

Dalam lima tahun terakhir tingkat pengangguran di Jawa Timur mengalami penurunan tahun 2008 tingkat pengangguran sebesar $6,42 \%$, tahun 2009 sebesar 5,08\%, tahun 2010 sebesar 4,25\%, tahun 2011 sebesar 4,16\% dan tahun 2012 sebesar 4,12\% dari tahun 2008 2012 tingkat pengangguran menurun sebesar 2,3\%, penurunan tingkat pengangguran terbuka ini menggambarkan ada beberapa faktor yang yang memberikan pengaruh pada tingkat pengangguran,ada beberapa faktor yang peneliti sajikan yaitu Pertumbuhan Ekonomi, Upah Minimum dan Indeks Pembangunan Manusia

Dari penjelasan latar belakang di atas maka penulis tertarik untuk melakukan penelitian dengan judul “Analisis Pengaruh Pertumbuhan Ekonomi, Upah Minimum, dan Indeks Pembangunan Manusia terhadap tingkat Pengangguran" dengan tujuan mengetahui distribusi dan klasifikasi tingkat pengangguran, pertumbuhan ekonomi, upah minimum dan Indeks 
pembangunan manusia di Provinsi Jawa Timur tahun 2008 - 2014 serta pengaruh pertumbuhan ekonomi, upah minimum dan indeks pembangunan manusia terhadap tingkat pengangguran di Provinsi Jawa Timur tahun 2008 - 2014.

\section{METODE PENELITIAN}

Ruang lingkup penelitian ini di lakukan di wilayah Jawa Timur pada tahun 2014 di mana menurut pembagian wilayah administrasi Indonesia, Provinsi Jawa Timur tahun 2008 - 2012 terdiri dari 9 kota dan 29 kabupaten.

Identifikasi daerah Tingkat pengangguran dapat dilakukan dengan mengklasifikasi intensitas daerah didasarkan atas jumlah Tingkat pengangguran ke dalam peringkat "sangat tinggi”, "tinggi", "sedang" dan "rendah". Pengklasifikasian didasarkan atas metode distribusi yang menggunakan rata-rata (mean)dan standar deviasi (SD), dimana simbol $\varnothing=$ (jumlah tingkat pengangguran) indikator di kelompokkan dalam tabel penentuan klasifikasi intensitas pada tabel 4 berikut ini:
Tabel 1. Klasifikasi Intensitas

\begin{tabular}{cc}
\hline \multicolumn{2}{c}{ Penentuan Klasifikasi Intensitas } \\
\hline Klasifikasi & Nilai Indikator \\
\hline Sangat & $\Phi \geq$ mean+SD \\
Tinggi & \\
\hline Tinggi & mean $\leq \Phi \leq$ mean + \\
& SD \\
\hline Sedang & mean - SD $\leq \Phi \leq$ \\
mean
\end{tabular}

Menurut Gujarati (1995) Data panel adalah data yang di peroleh dengan menggabungkan antara data cross-section dan data time series. Ada tiga teknik yang bias di gunakan dalam regresi data panel yaitu teknik OLS (Common Effect), Fixed Effect dan Random effect .Untuk menetukan teknik yang paling tepat untuk mengetstimasi data panel, harus melelui tiga uji yaitu uji $\mathrm{F}$, uji LM dan uji Housman. Metode yang di gunakan adalah:

$$
Y_{i t}=\mathrm{a}+\beta_{1} X_{i t}+\beta_{2} \dot{X}_{t t}+\beta_{3} X_{i t}+e_{i t}
$$

Dimana:

$$
\begin{aligned}
& \mathrm{Y}_{\mathrm{it}}=\text { Tingkat pengangguran }(\%) \\
& \mathrm{a}=\text { Konstanta } \\
& \mathrm{X} 1=\text { Pertumbuhan ekonomi }(\%) \\
& \mathrm{X} 2=\text { Upah minimum }(\%) \\
& \mathrm{X} 3=\mathrm{IPM}(\%)
\end{aligned}
$$




\section{PEMBAHASAN}

Tingkat Pengangguran di tahun 2008 terbanyak di kelas interval antara $2,93 \%-4,93 \%$ yaitu 15 daerah dan sedikit di kelas interval antara $8,93 \%$ - 10,93\% yaitu 3 daerah, tahun 2009 terbanyak di kelas inteval antara 3,32\% 5,32\%yaitu 14 daerah dan sedikit di kelas interval antara11,32\% - 13,32\% yaitu 1 daerah.tahun 2010 terbanyak di kelas interval antara $2,87 \%$ 3,87\% yaitu 17 daerahdan sedikit di kelas interval antara $8,87 \%-9,87 \%$ yaitu 3 daerah, tahun 2011 terbanyak di kelas interval antara 3,70\% $4,70 \%$ yaitu18 daerah dan sedikit di kelas interval antara 5,76\% - 6,70\% yaitu 1 daerah, tahun 2012 terbanyak di kelas interval antara 3,16\% 4,16\%dengan jumlah 14 dan sedikti di kelas interval antara 1,16 - 2,16 yaitu 4 daerah.

Pertumbuhan Ekonomi tahun 2008 terbanyak di kelas interval antara 5,31 - 6,32 yaitu 21 daerah dan sedikit di kelas interval antara 8,31-9,31 yaitu 1 daerah, tahun 2009 terbanyak di kelas inteval antara 4,19 - 5,19 yaitu 30 daerah dan sedikit di kelas interval antara 6,19 - 7,19 yaitu
1 daerah. tahun 2010 terbanyak di kelas interval antara 6,4 - 6,5 yaitu 22 daerah dan sedikit di kelas interval antara 7,4 - 8,4 yaitu 2 daerah, tahun 2011 terbanyak di kelas interval antara 6,14 - 7,14 yaitu 26 daerah dan sedikit di kelas interval antara 9,14 - 10,14 yaitu 1 daerah, tahun 2012 terbanyak di kelas interval antara 5,83 - 6,83 dengan jumlah 19 dan sedikti di kelas interval antara 7,83 - 8,83 yaitu 2 daerah.

Distribusi upah minimum di tahun 2008 terbanyak di kelas interval antara 500.000 - 551.000 yaitu 13 daerah dan sedikit di kelas interval antara $551.000-602.000$ yaitu 2 daerah, tahun 2009 terbanyak di kelas inteval antara 570.000 637.000 yaitu 11 daerah dan sedikit di kelas interval antara 838.000 905.000 yaitu 2 daerah. tahun 2010 terbanyak di kelas interval antara 630.000 - 697.000 yaitu 15 daerah dan sedikit di kelas interval antara 898.000 - 965.000 atau 697.000 764.000 yaitu 3 daerah, tahun 2011 terbanyak di kelas interval antara 705.000 - 778.000 yaitu 15 daerah dan sedikit di kelas interval antara 
991.000 - 1.062 .000 yaitu 1 daerah, tahun 2012 terbanyak di kelas interval antara $745.000-831.000$ dengan jumlah 16 daerah dan sedikti di kelas interval antara 1.003.000 1.089.000 yaitu 1 daerah.

Distribusi Upah Minimum di tahun 2008 terbanyak di kelas interval antara $500.000-551.000$ yaitu 13 daerah dan sedikit di kelas interval antara $551.000-602.000$ yaitu 2 daerah, tahun 2009 terbanyak di kelas inteval antara 570.000 637.000 yaitu 11 daerah dan sedikit di kelas interval antara 838.000 -
905.000 yaitu 2 daerah. tahun 2010 terbanyak di kelas interval antara 630.000 - 697.000 yaitu 15 daerah dan sedikit di kelas interval antara 898.000 - 965.000 atau 697.000 764.000 yaitu 3 daerah, tahun 2011 terbanyak di kelas interval antara 705.000 - 778.000 yaitu 15 daerah dan sedikit di kelas interval antara 991.000 - 1.062 .000 yaitu 1 daerah, tahun 2012 terbanyak di kelas interval antara $745.000-831.000$ dengan jumlah 16 daerah dan sedikti di kelas interval antara 1.003.0001.089.000 yaitu 1 daerah.

\section{Gambar 1. Klasifikasi Tingkat Pengangguran Tahun 2008}

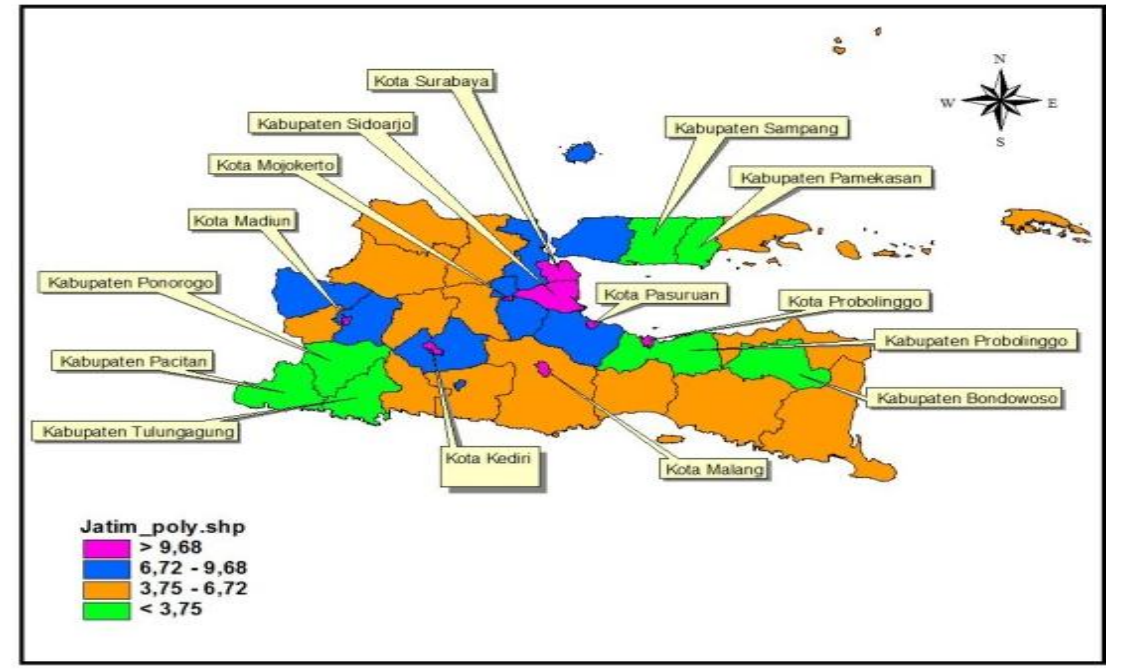

Sumber : GIS Data hasil Olahan

Tahun 2008 untuk klasifikasi tingkat Pengangguran katagori sangat tinggi ada sekitar 7 Kota dan 1 Kabupaten yang terdiri dari Kota
Surabaya, Kabupaten Sidoarjo, Kota Malang, Kota Mojokerto, Kota Pasuruan, Kota Probolinggo, Kota Kediri dan Kota Madiun klasifikasi 
kategori rendah, ada sekitar 4 Bondowoso, Kabupaten Pamekasan Kabupaten yang terdiri dari dan Kabupaten Sampang.

Kabupaten Pacitan, Kabupaten

\section{Gambar 2. Klasifikasi Tingkat Pengangguran Tahun 2012}

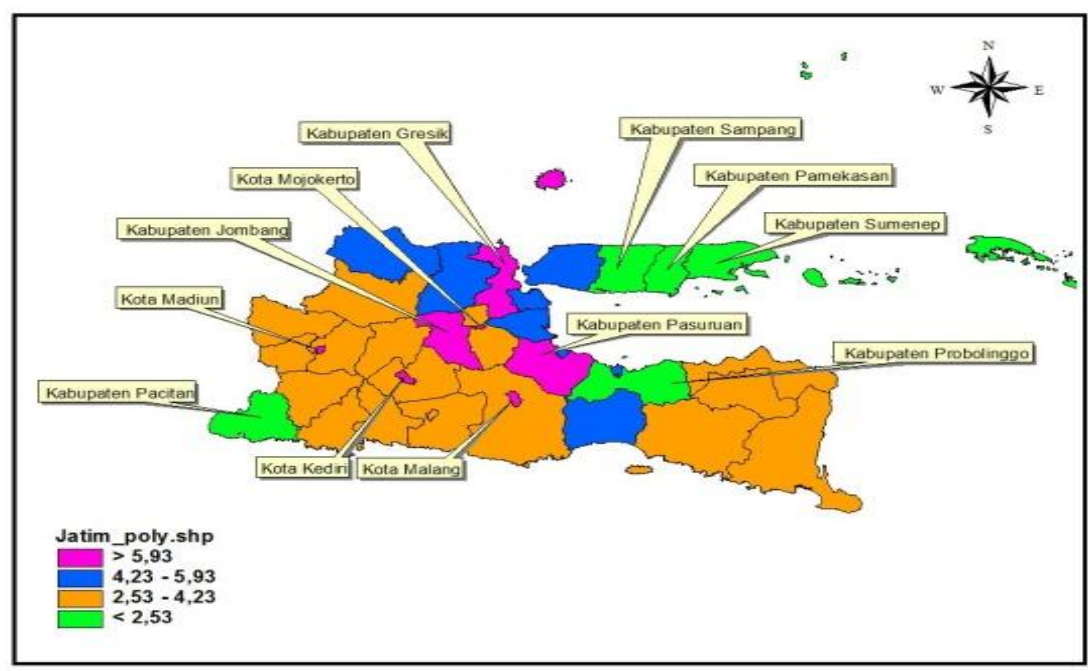

Sumber : GIS Data hasil Olahan

Tahun 2012 untuk klasifikasi tingkat pengangguran sangat tinggi sekitar 5 Kota dan 2 Kabupaten terdiri dari Kabupaten Gresik, Kabupaten Pasuruan, Kota Malang, Kota Mojokerto, Kota Kediri, Kota Madiun dan Kabupaten Jombang. klasifikasi tingkat pengangguran rendah ada sekitar 1 kota dan 13 Kabupaten yang terdiri dari Kabupaten Mojokerto, Kota Batu, Kabupaten Probolinggo, Kabupaten Banyuwangi, Kabupaten Ponorogo, Kabupaten Blitar, Kabupaten Trenggalek, Kabupaten Ngawi. 


\section{Gambar 3. Klasifikasi Pertumbuhan Ekonomi Tahun 2008}

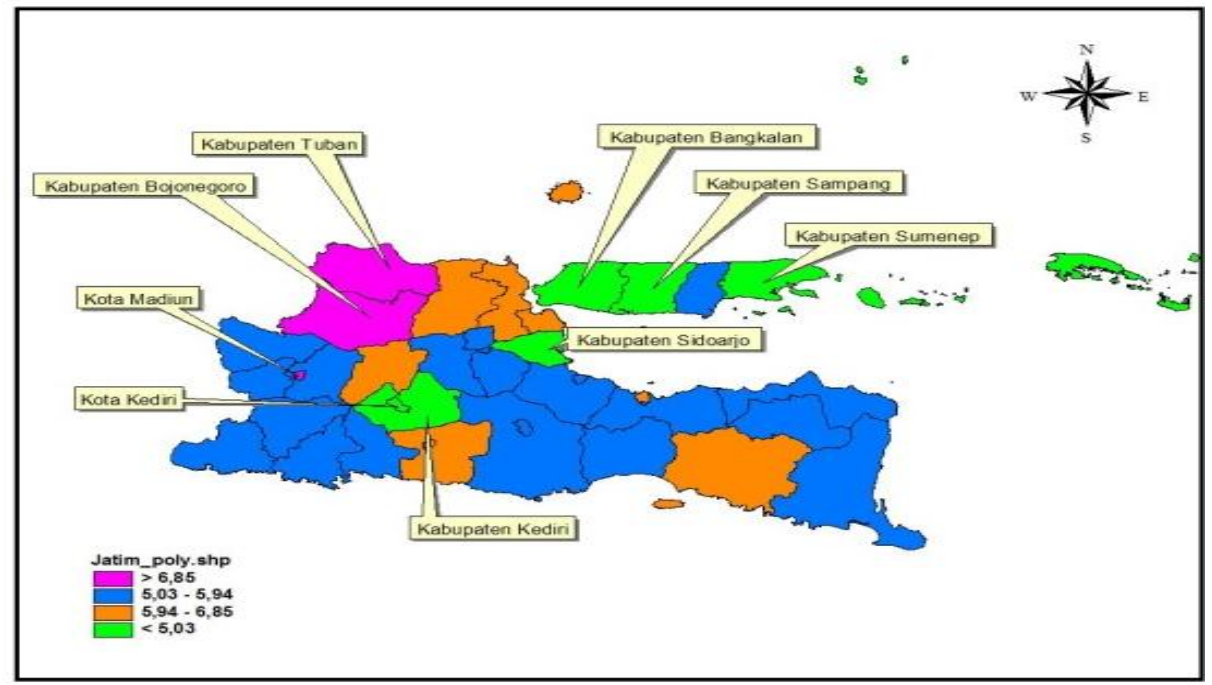

Sumber : GIS Data hasil Olahan

Klasifikasi sangat tinggi di klasifikasi rendah terdapat 3 daerah tahun 2008 yaitu Kabupaten yaitu Kabuatn Bangkalan, Kabupaten Bojonegoro, Kabupaten Tuban, Kota Sampang dan Kabupaten Sumenep. madiun dan Kota Batu. Untuk hasil

\section{Gambar 4. Klasifikasi Pertumbuhan Ekonomi Tahun 2012}

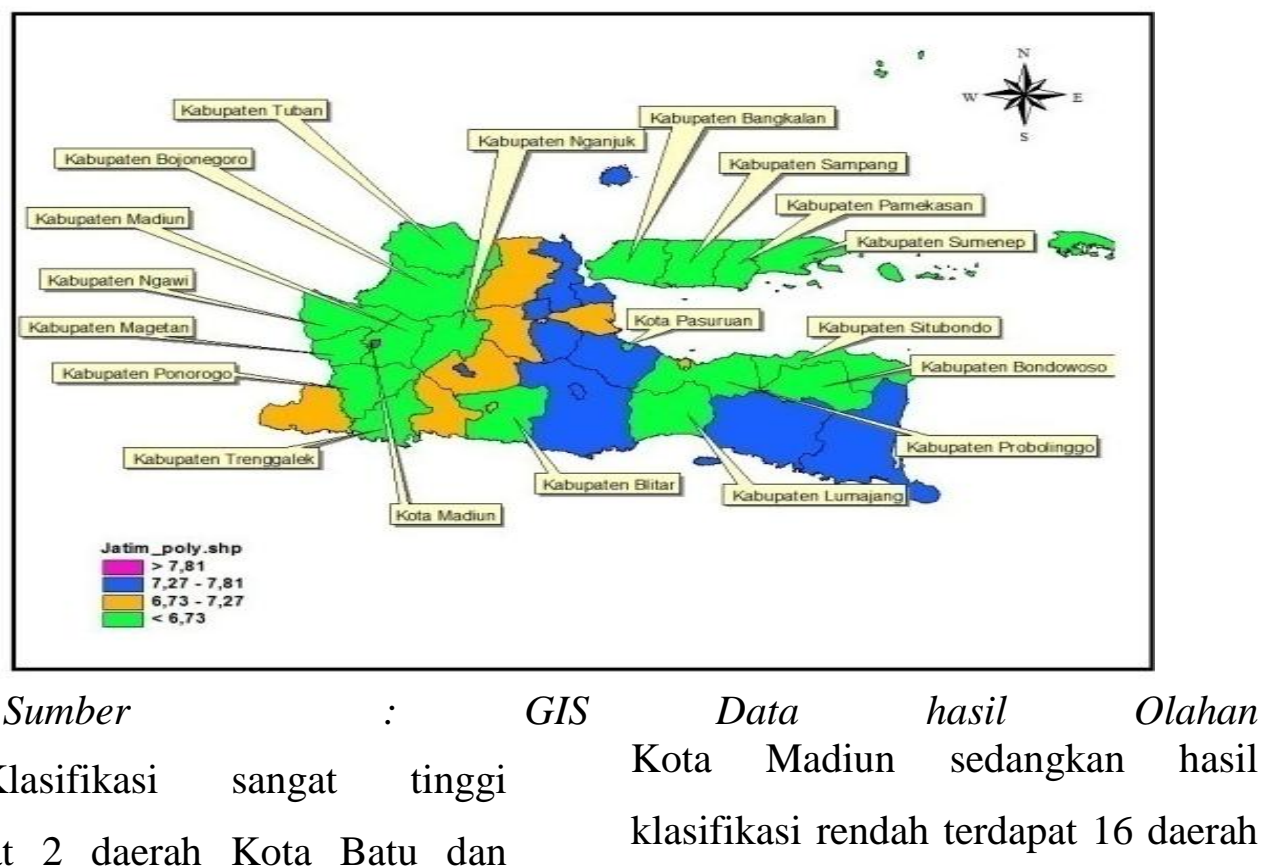

terdapat 2 daerah Kota Batu dan 
yaitu Kabupatn Ponorogo, Magetan, Kabupaten Ngawi, Kabupaten Trenggalek, Kabupaten Kabupateann Bojonegoro, Blitar , Kabupaten Lumajang, Kabupaten Tuban, Kabupaten Kabupaten Bondowoso, kabupaten Bangkalan, Kabupaten Sampang, Situbondo, Kabupaten Probolinggo, Kabupaten Pamekasan, Kabupaten Kabupaten Nganjuk, kabupaten Sumenep dan Kabupaten Pasuruan Madiun, Kabupaten , Kabupaten

\section{Gambar 5. Klasifikasi Upah Minimum Tahun 2008}

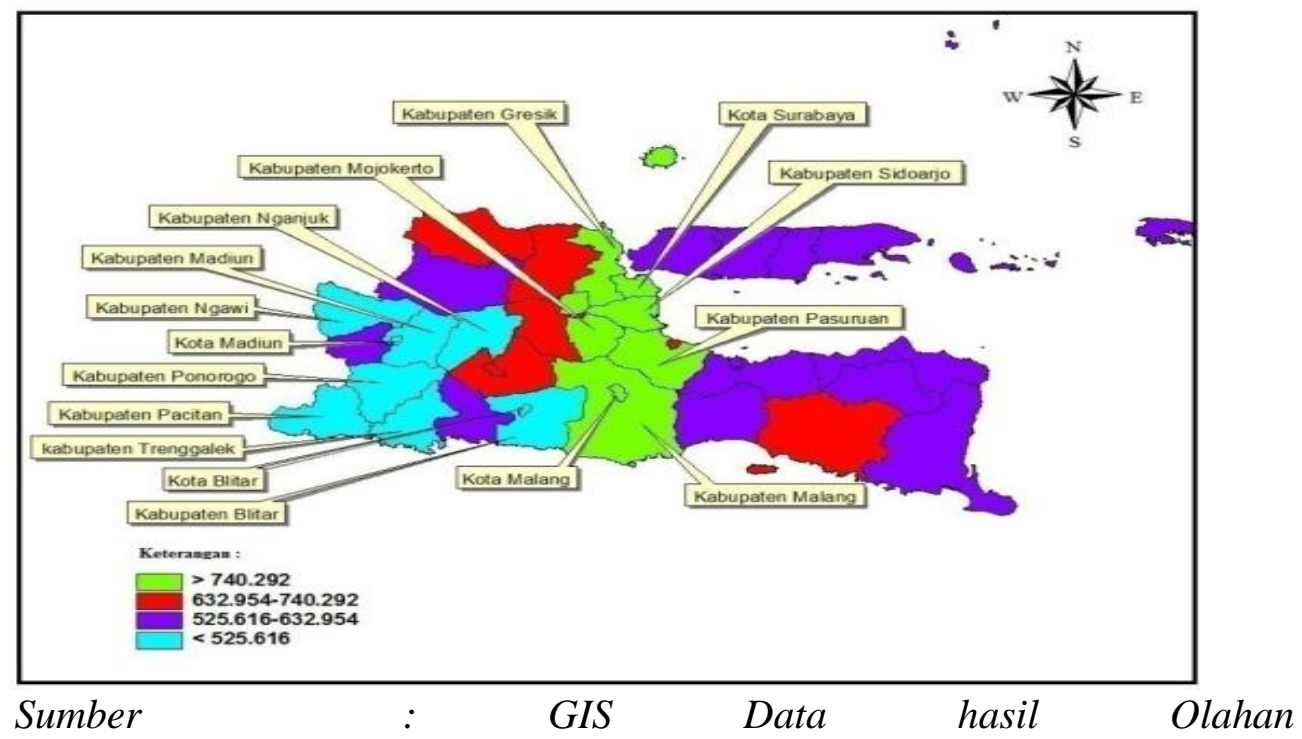

Klasifikasi sangat tinggi yaitu kabupaten Pacitan, Kabupaten terdapat di tujuh daerah yaitu Trenggalek, Kabupaten Ponorogo, kabupaten Malang, Kabupaten Kabupaten Blitar, kabupaten Pasuruan, Kabupaten Mojokerto, Nganjuk, Kabupaten Madiun, Kabupaten Sidoarjo, Kabupaten Kabupaten Ngawi, Kota Blitar dan Gresik, kota Malang dan Kota Kota Madiun.

Surabaya. sedangkan untuk hasil klasifikasi rendah terdapat daerah 
Gambar 6. Klasifikasi Upah Minimum Tahun 2012

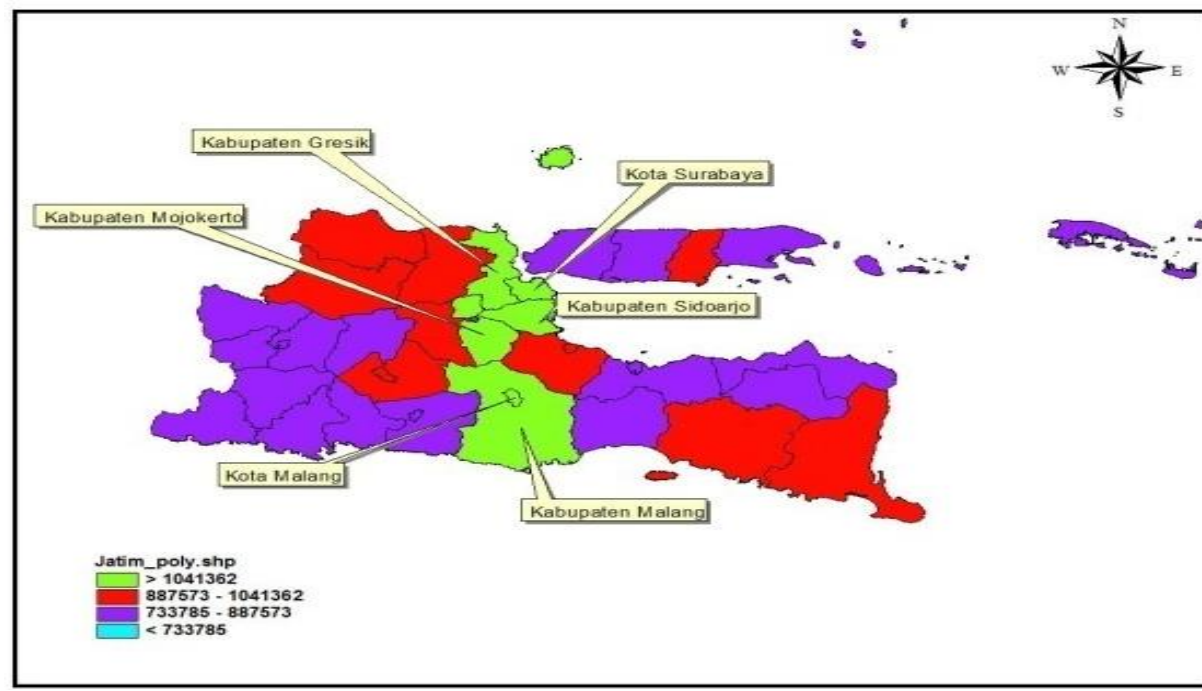

Sumber : GIS Data hasil Olahan

Klasifikasi tahun 2012 sangat

tinggi terdapat 7 daerah yaitu

Kabupaten Malang, kabupaten

Sidoarjo, Kabupaten Mojokerto ,
Kabupaten Gresik, Kota Malang,

Kota Surabaya dan Batu.

Sedangakan untuk klasifikasi rendah tidak ada

\section{Gambar 7. Klasifikasi Indeks Pembangunan Manusia Tahun 2008}

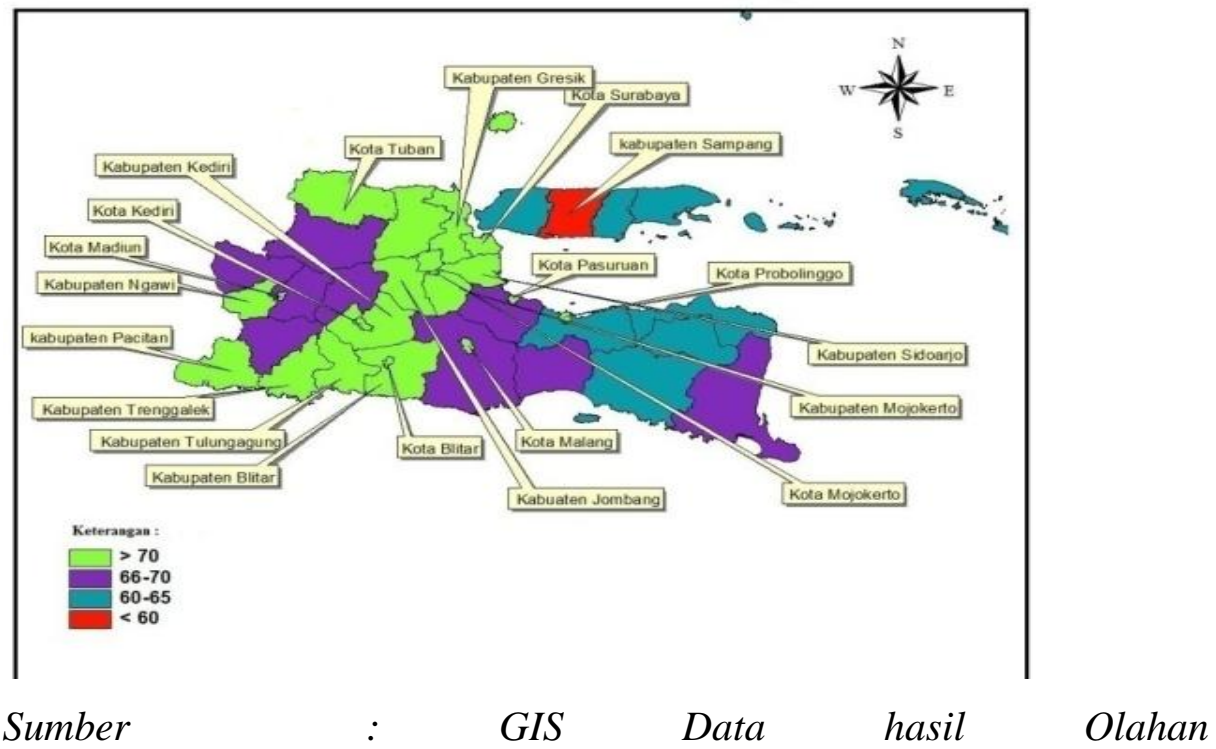


Tahun 2008, Klasifikasi Tinggi terdapat 18 daerah yaitu Kabupaten Pacitan, Kabuapaten Trenggalek, kabupaten tulungagung, kabupaten Blitar, Kabupaten Kediri, Kabupaten Sidoarjo, Kabupaten Jombang, kabupaten Magetan, Kabupaten
Gresik, Kota batu, Kota Surabaya, Kota Madiun, Kota Mojokerto, Kota pasuruan, Kota Probolinggo, Kota Malang, Kota Kediri dan Kota blitar, sedangkan untuk klasifikasi rendah terdapat 1 daerah yaitu Kabupaten Sampang.

\section{Gambar 8. Klasifikasi Indeks Pembangunan Manusia Tahun 2012}

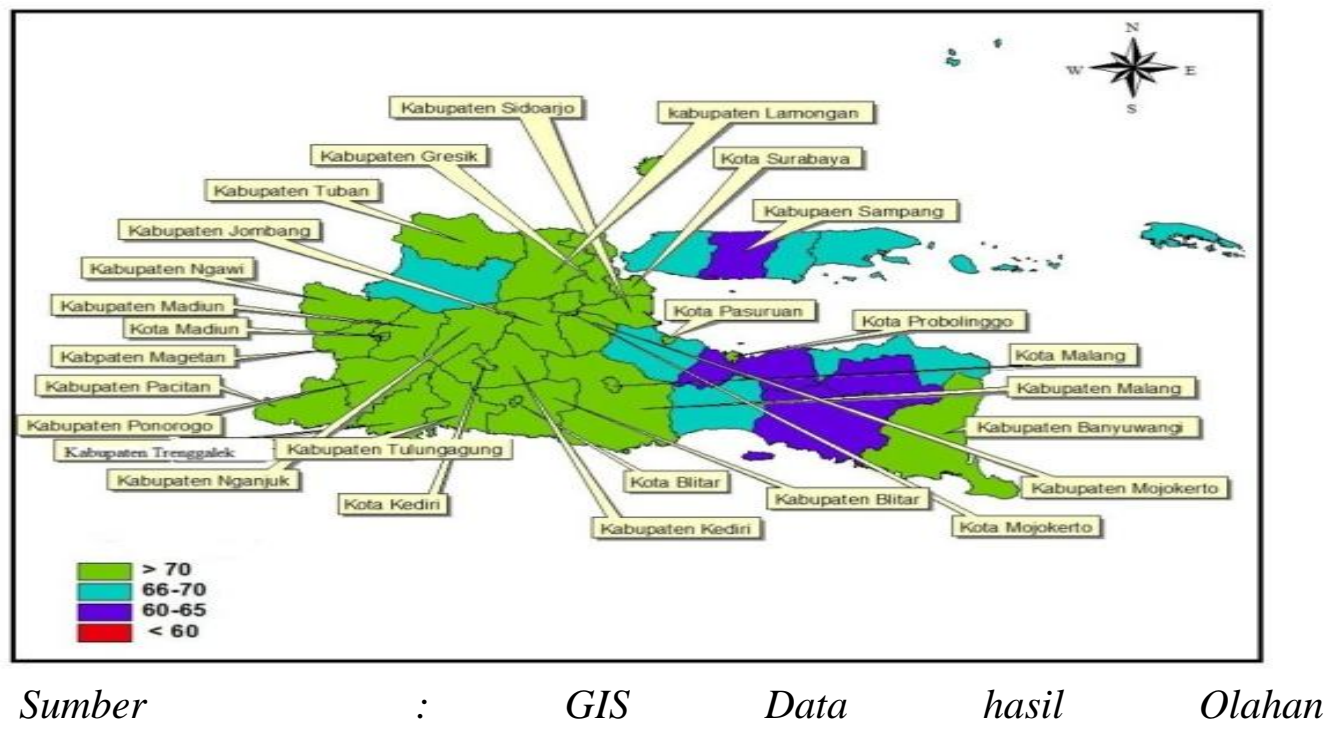

Tahun 2012, klasifikasi tinggi terdapat di 26 daerah yaituKabupaten Pacitan, Kabupaten Ponorogo, Kabuapaten Trenggalek, kabupaten tulungagung, kabupaten Blitar, Kabupaten Kediri, Kabupaten Sidoarjo, Kabupaten Jombang, kabupaten Magetan, Kabupaten Ngawi,kabupaten Nganjuk, Kabupaten Madiun , kabupaten banyuwangi, Kabupaten Gresik, Kota batu, Kota Surabaya, Kota
Madiun, Kota Mojokerto, Kota pasuruan, Kota Probolinggo, Kota Malang, Kota Kediri ,Kabupaten Lamongan, kabupaten Gresik dan Kota blitar. sedangkan untuk klasifikasi rendah tidak ada

Uji Statistik F Nemurator 37 dan denumerator $=190-3=187$, pada $\alpha=5 \%(0,05)$ diperoleh nilai $\mathrm{F}_{\text {tabel }}=1,47$ Dari hasil uji $\mathrm{F}$ diperoleh nilai $F_{\text {hitung }}=11,73$ jadi nilai $F_{\text {hitung }} 11,73>F_{\text {tabel }} 1,47$ maka 
dapat disimpulkan bahwa Ho ditolak dan $\mathrm{Ha}$ diterima ,berati model fixed effect yang paling tepat.

Uji Langrange Multiplier nilai df sebesar 3 pada $\propto=5 \%(0,05)$ diperoleh nilai $\mathrm{X}_{2}$ sebesar 7,81473 dari hasil uji LM diperoleh nilai $\mathrm{LM}_{\text {hitung }} 68.077 .007>\mathrm{X}_{2} \quad 7,81473$ maka dapat disimpulkan bahwa Ho ditolak dan Ha diterima, berati model Random Effect merupakan model yang tepat.

Uji Hausman pada $\alpha=5 \%$ $(0,05)$ diperol

\begin{tabular}{crrrr} 
Variable & Coefficient & Std. Error & t-Statistic & Prob. \\
\hline \hline C & 47.41117 & 10.35324 & 4.579354 & 0.0000 \\
GR? & -0.461042 & 0.140681 & -3.277203 & 0.0013 \\
UM? & -10.50619 & 1.928101 & -5.448982 & 0.0000 \\
IPM? & 0.315702 & 0.051233 & 6.162041 & 0.0000 \\
GLS Transformed & & & & \\
$\quad$ Regression & & & & \\
\hline \hline R-squared & 0.659950 & Mean dependent var & 4.996526 \\
Adjusted R-squared & 0.654465 & S.D. dependent var & 2.383389 \\
S.E. of regression & 1.401009 & Sum squared resid & 365.0858 \\
Durbin-Watson stat & 1.070696 & & \\
\hline \hline
\end{tabular}
Durbin-Watson stat 1.070696

Unweighted Statistics including Random Effects

\begin{tabular}{llll}
\hline \hline R-squared & 0.752574 & Mean dependent var & 4.996526 \\
Adjusted R-squared & 0.748583 & S.D. dependent var & 2.383389 \\
S.E. of regression & 1.195067 & Sum squared resid & 265.6423 \\
Durbin-Watson stat & 1.471513 & & \\
\hline \hline
\end{tabular}

Tabel.2 Hasil Analisis Regresi Linier Berganda Data Panel Hasil Analisis Regresi Model Random Effect 
Sumber : eviews (data diolah)

$\beta_{1} \quad\left(\ln \mathrm{X}_{1}\right) \quad=-0.461042 \quad(-\quad$ jumlah pengangguran diberikan akan $46,10 \%)$, koefisien regresi variabel turun $10,50 \%$ dengan asumsi pertumbuhan ekonomi menunjukan ada pengaruh negatifantara pertumbuhan ekonomi (X1) terhadaptingkat pengangguran $(\mathrm{Y})$ sebesar $(-46,10) \%$. jika jumlah pertumbuhan ekonomi turun sebesar $1 \%$, maka jumlah pertumbuhan ekonomi yang diberikan akan turun sebesar $-46,10 \%$ dengan asumsi variabel lainnya tidak mengalami perubahan

$$
\beta_{2} \quad\left(\ln \mathrm{X}_{2}\right)=-10.50619
$$

$(10,50 \%)$, koefesien regresi variabel upah minimu menunjukan ada pengaruh negatif antara upah minimu $\left(\mathrm{X}_{2}\right)$ terhadap pengangguran $(\mathrm{Y})$ sebesar 10,50\%. jika jumlah upah minimum naik sebesar $1 \%$, maka variabel lainnya tidak mengalami perubahan (tetap).

$$
\beta_{3}\left(\ln X_{3}\right)=0.315702 \quad(31,57
$$
$\%)$, koefesien regresi variabel Indeks Pembangunan menunjukan ada pengaruh positif antara Indeks pembangunan manusia $\left(\mathrm{X}_{3}\right)$ terhadap tingkat pengangguran (Y) sebesar $31,57 \%$. jika IPM naik sebesar 1\%, maka jumlah jumnlah pengangguran akan naik 31,57\% dengan asumsi variabel lainnya tidak mengalami perubahan (tetap).

Hasil Uji F (simultan) nilai $\mathrm{df}_{1}$ sebesar 3 dan $\mathrm{df}_{2}=\mathrm{n}-\mathrm{k}-1=$ sebesar 186 pada $\alpha=5 \%(0,05)$ diperoleh nilai $\mathrm{F}_{\text {tabel }}=2.65$ nilai $\mathrm{F}_{\text {hitung }}=$ 188,61. nilaiF $F_{\text {hitung }}>\mathrm{F}_{\text {tabel }}$ 
$(188,61>2.65)$. maka dapat ditarik kesimpulan bahwa Ho ditolak dan Ha diterima artinya variabel bebas berpengaruh secara serentak terhadap variabel terikat dengan hasil yang signifikan

Uji $t$ untuk variabel Pertumbuhan ekonomi (X1) terhadap variabel pengangguran (Y)Dengan alfa 5\%, $\mathrm{n}=190$ dan df $=$ n-k-1= 186 ,t tabel sebesar 1.65304 dan t hitung $=-3.387976$.

Untuk regresi 1 pengaruh pertumbuhan ekonomi terhadap tingkat pengangguran di kabupaten dan kota di provinsi jawa timur memiliki nilai $t_{\text {hitung }}$ sebesar 3.277203 dengan nilai probabilitas 0.0013. Hal ini menunjukan nilai $t_{\text {hitung }}>t_{\text {tabel }} \quad(-3.277203>-1,65) \quad$ dan nilai probabilitas 0.0013 pada $\alpha=5$ \% $(0,05)$ maka Ho ditolak dan $\mathrm{Ha}$ diterima. Dengan demikian dapat disimpulkan bahwa variabel Pertumbuhan ekonomi $\left(\mathrm{X}_{3}\right)$ berpengaruh secara nyata dan signifikan terhadap pertumbuhan ekonomi (Y) di kabupaten dan kota jawa timur

Uji $t$ untuk variabel Upah Minimum (X2) terhadap variabel
Pengangguran (Y) Dengan alfa $5 \%$, $\mathrm{n}=190$ dan $\mathrm{df}=\mathrm{n}-\mathrm{k}-1=186, \mathrm{t}$ tabel sebesar 1.65304 dan $\mathrm{t}$ hitung $=$ 5.448982 .

Untuk regresi 2 pengaruh Upah Minimum terhadap Pengangguran di kabupaten dan kota di jawa timur.memiliki nilai $t_{\text {hitung }}$ sebesar-5.448982 dengan nilai -probabilitas sebesar 0,0000. Hal ini menunjukan nilai $t_{\text {hitung }}>t_{\text {tabel }} \quad(-$ $5.448982>-1,65)$ dan nilai probabilitas 0,0000 pada $\alpha=5 \%$ $(0,05)$ maka Ho ditolak dan $\mathrm{Ha}$ diterima. Dengan demikian dapat disimpulkan bahwa variabel upah minimum $\left(\mathrm{X}_{2}\right)$ berpengaruh secara nyata dan signifikan terhadap pengangguran (Y), di kabupaten dan kota di jawa timur.

Uji t untuk variabel IPM (X3) terhadap variabel Penganggurn (Y)Dengan alfa 5\%, n=190 dan df = $\mathrm{n}-\mathrm{k}-1=187, \mathrm{t}$ tabel sebesar 1,65 dan $\mathrm{t}$ hitung $=6.162041$

Untuk regresi 3 pengaruh IPM terhadap Pengangguran di kabupaten dan kota di jawa timurmemiliki nilai $t_{\text {hitung }}$ sebesar6.162041 dengan nilai probabilitas sebesar 0,0000. Hal ini menunjukan nilai $t_{\text {hitung }}>t_{\text {tabel }}$ 
$(6.162041>1,65)$ dan nilai probabilitas 0,0000 pada $\alpha=5 \%$ $(0,05)$ maka Ho ditolak dan $\mathrm{Ha}$ diterima. Dengan demikian dapat disimpulkan bahwa variabel IPM $\left(\mathrm{X}_{3}\right)$ berpengaruh secara nyata dan signifikan terhadap pertumbuhan ekonomi (Y)

Untuk melihat model persamaan regresi diatas, apakah tergolong baik atau tidak, maka dapat dilihat dari nilai koefisien determinasi (Goodness and Fit) atau $R^{2}$. Pengujian ini dapat mengukur seberapa besar kontribusi variabel bebas secara keseluruhan dalam pembentukan model, bahwa koefisien $\mathrm{R}^{2}$ sebesar $0.752574(75,25 \%)$, berarti bahwa keberadaan variable pertumbuhan eknomi (X1), upah minimum (X2) dan IPM (X3) mampu memberikan kontribusi dalam menjelaskan Pengangguran sebesar 75,25\%, sedangkan sisanya $24,75 \%$ dijelaskan variable lain diluar model

\section{PENUTUP}

Berdasarkan hasil analisis dan pembahasan hasil penelitian, maka dapat diambil kesimpulan sebagai berikut:

1. Distribusi tingkat pengangguran terbuka, pertumbuhan ekonomi, upah minimum dan indeks pembangunan manusia di Kabupaten dan kota Jawa Timur tahun 2008 - 2012 tiap tahun menunjukan indikator yang positif artinya tingkat pengangguran Kabupaten dan Kota di Jawa Timur mengalami penurunan tiap tahun dan hal ini di imbangi dengan meningkatnya pertumbuhan ekonomi, upah minimum dan indeks pembangunan manusia.

2. Klasifikasi tingkat pengangguran terbuka, pertumbuhan ekonomi, upah minimum dan indeks pembangunan manusia di Kabupaten dan kota Jawa Timur tahun 2008 - 2012 tiap tahun menunjukan adanya perbedaan klasifikasi di tiap daerah hal ini menunjukan kemampuan tiap daerah yang masih belum merata secara menyeluruh.

3. Dari hasil penelitian ini menunjukan bahwa pertumbuhan ekonomi, upah minimum dan 
Indeks Pembangunan Manusia berpengaruh signifikan terhadap tingkat pengangguran.

\section{DAFTAR PUSTAKA}

Akbar Sis Putro. Achma Hendra Setiawan. 2011. Analisis Pengaruh PDRB, Upah minimum kota, Inflasi dan tanggungan penduduk terhadap pengangguran terbuka dikota magelang tahun 1990 - 2010. -

Anjarwati. 2013. Analisis Pengaruh

Fungsi Intemediasi Perbankan Terhadap Pertumbuhana

Ekonomi Di Indonesia (Periode

Tahun 2008-2011). Skripsi

Fakultas Ekonomi dan Bisnis

Universitas Muhammadiyah

Malang.

Badan Pusat Statistik. 2012.

Keadaan Angkatan Kerja 2007-

2011.Jawa Timur.

Badan Pusat Statistik. 2012. Keadaan

Angkatan Kerja 2012. Jawa

Timur.

Badan Pusat Statistik. 2013.

Pertumbuhan Ekonomi Jawa

Timur 2008 - 2012. Jawa

Timur
Badan Pusat Statistik Jawa Timur

dalam angka. 2013. Jawa

Timur.

Badan Pusat Statistik. 2012. Nilai

Minimum dan Maksimum Indikator Komponen IPM. Jawa Timur.

BPS - Bappenas - UNDP. 2001. Indonesia Human Development Report 2001. Towards a New Consensus: Democracy and Human Development in Indonesia. Jakarta: BPS Statistics Indonesia, Bappenas dan UNDP Indonesia.

BPS-Bappenas-UNDP. 2004. National Human Development Report 2004. The Economics of Democracy: $\quad$ Finanncing Human Development in Indonesia. Jakarta: BPSStatistics Indonesia, Bappenas dan UNDP Indonesia.

Dinas Tenaga kerja, Transmigrasi dan Kependudukan. 2011. Penetapan Upah Minimum Kabupaten dan Kota 2008 2010. Jawa Timur

Dinas Tenaga kerja, Transmigrasi dan Kependudukan. 2011. Penetapan Upah Minimum 
Kabupaten dan Kota 2011.

Jawa Timur

Dinas Tenaga kerja, Transmigrasi dan Kependudukan. 2012. Penetapan Upah Minimum Kabupaten dan Kota 2012. Jawa Timur: Dinaskertransduk.

Gujarati, Damodar. 1995.

Ekonometrika Dasar. Jakarta:

Erlangga

Ilmu Ekonomi Studi Pembangunan,

Laboratorium. 2011. Modul

Program Eviews. Fakultas

Ekonomi dan Bisnis

Universitas Muhammadiyah

Malang

Mankiw, N. Gregory. 2010. Teori

Ekonomi Makro Edisi

Keenam.Erlangga. Jakarta.

Mudrajad Kuncoro. 2002. Analisis

Spasial dan Regional: Studi

Aglomerasi dan KlusterIndustri

Indonesia, UPP AMP YKPN,

Muhammad Shun Hajji, Nugroho

SBM. 2013. Analisis Pengaruh

Upah, PDRB danangka melek

huruf terhadap Pengangguran

terbuka di provinsi jawa tengah

tahun 1990 - 2011

Roby Cahyadi Kurniawan. 2013.

Analisis Pengaruh PDRB,
UMK, dan InflasiTerhadap Tingkat Pengangguran Terbuka di Kota Malang Tahun 1980 2011.

Simanjuntak, Payaman J. 1998. Pengantar Ekonomi Sumber Daya Manusia. Jakarta: LPFEUI.

Sukirno, Sadono. 2010. Makro Ekonomi Teori Pengantar, Jakarta: PT. Raja. Grafin Persada

Sulistyastuti, Dya Ratih. 2004. Dinamika Usaha Kecil dan Menengah (UKM) Analisis Konsentrasi Regional UKMdi Indonesia 1999 - 2001. Jurnal EkonomI Pembangunan Vol 9. Sugiyono. 2011. Metode Penelitian Kuantitatif, kualitatif dan R \& D. Bandung: Alfabeta.

Todaro, Michael P. 2003. Pembangunan Ekonomi di Dunia Ketiga.Penerjemah: Haris Munandar. Jakarta: Erlangga

Tim penyususun. 2010. Buku Pedoman Penulisan Skripsi dan Tugas Akhir.FEB UMM 
Analisis Pengaruh Pertumbuhan Ekonomi........ Muhammad Nurcholis 